\title{
In Search of a Cure for Melancholia: The Attitude of a Listener in the Short Story Wśród lasu [Among the Forest] by Adam Asnyk
}

\begin{abstract}
In my article I interpret the short story Wśród lasu [Among the Forest] by Adam Asnyk. I discuss the issue of the relationship between auditory perception and melancholic experiences. To this end, while analyzing the text, I refer to concepts regarding the nature of melancholia and adopt the methodological apparatus of sound studies. As it turns out, the listener's attitude is crucial for overcoming melancholia. According to the poet, attentive listening to the surroundings and the words of other people allows to reach the meaning of life inscribed in nature and as a consequence may help find a cure for melancholia.

Keywords: Adam Asnyk, auditory perception, book of nature, cure for melancholia, attitude of a listener
\end{abstract}

\section{Introduction}

Adam Asnyk's ${ }^{1}$ prose is rarely the subject of academic research. Except for a brief discussion in the monograph by Baczewski (1984, pp. 277-298), it is difficult to find a scientific study of that topic. Asnyk's poetry has aroused much more interest, also in recent years - suffice to mention the extensive dissertation by Dąbrowska (2013) or the book by Budrewicz (2015). In his study, the researcher focuses on the socio-political interpretation of Asnyk's poems, but at the same time he points out that "the poet's portrait preserved in the history of literature exposes the melancholia and philosophical distance of a wise sage brooding over the rights of being"2 (p. 5). The indicated issues, so characteristic of Asnyk's works, were also taken up by him in W'ród lasu [Among the Forest] published in 1877. This little-known short story touches upon the problem of seeking a cure for melancholia.

1 Polish writer who lived in the years 1838-1897. Related by generation to the Polish Positivist school of thinking and recognized as the leading poet of that period (Nofer, 1965).

2 All translations of quotes from Polish texts are mine, unless otherwise indicated.

Magdalena Krzyżanowska, Instytut Literatury Polskiej, Wydział Polonistyki, Uniwersytet Warszawski, ul. Krakowskie Przedmieście 26/28, 00-927 Warszawa, magdalena.m.krzyzanowska@gmail.com, http://orcid.org/0000-0002-3801-5940 
I intend to discuss this issue in my article. The starting point for my considerations is to determine how Asnyk understands melancholia in his work. For this purpose, I will refer to the famous concepts regarding the nature of this phenomenon. Consequently, I shall address the problematics of an influence of auditory and visual stimuli on the melancholic person. To this end, I will adopt the conceptual and methodological apparatus of sound studies. The problem of sight, although frequently commented on, will be regarded as of secondary importance. I would like to focus primarily on the description of the sound experience, as the link between melancholia and audio cues is much less recognized and as such remains barely examined in source literature. In addition, as is my opinion, the indicated issues relate directly to the major theme of Asnyk's short story, and their conceptualization may be facilitative to its reinterpretation.

In my analysis of the representation of sounds in Asnyk's work I shall employ three basic terms: audiosphere, soundscape, and listening-in-readiness. The first of them - the audiosphere - is defined by Misiak (2009) as sounds determining the specificity of a given space (pp. 35-39). I will use it to determine and map out the sounds discernible in the forest area, which will be understood as a veritable sonic space within the story. More important for me will be the concept of a soundscape introduced by Schafer (1977), apprehended as a studied acoustic environment. As Losiak (2015, p. 46) points out, it is associated with the individual reception of the audiosphere and situates its recipient in the center. Truax (1984), developing in his research Schafer's theory of acoustic ecology ${ }^{3}$, proposed his own concept of acoustic communication, which "attempts to understand the interlocking behavior of sound, the listener and the environment as a system of relationships, not as isolated entities" (p. xii). According to this theory, listening is an activity that requires conscious attention. It consists of capturing the difference between various stimuli, which are carriers of information transmitted by the miscellaneous noises in the surroundings themselves. The concept of listening understood in this way is the very foundation of this communication (pp. 16-17).

In my re-reading of Asnyk's story, the issue of paramount significance is the relation between the protagonist, identified as the target of sonic stimuli, and the represented sound environment. I will also consider the type of information conveyed to the character through the sounds of the surroundings and the speech, as well I will analyze the possible meaning behind the listener's attitude. In my opinion, among the types of listening enumerated by Truax, the term listeningin-readiness will prove most useful. It is the level of reception in which different variants of stimuli are received (also from other senses) and the audio ones can be captured, extracted, and subsequently decoded. This is facilitated by the essential

\footnotetext{
3 Nacher discusses both theories in her article (2010).
} 
quality of the environment, in this case, the forest. In this sense, the sounds are particularly dependent on the context in which they resound (pp. 19-21).

Thus, the main ambition of my article is to show the correlations between the presentation of the auditory perception of the protagonist, identifiable also by various representations of sounds, and the way of describing his melancholic experiences.

\section{Discussion}

The issue of melancholia relates predominantly to the attitude of the protagonist, Edward, who describes himself as one of those "who always seek but cannot find anything" (Asnyk, 2004, p. 25). His behavior, life-attitude, and even his appearance reveal that he was intended to be a melancholic character. Edward has handsome and noble facial features, however marred by traces of prolonged mental fatigue, and bitterness. He often falls into apathy or tends to dream. At the same time, the protagonist remains perpetually disappointed and disgruntled. He also grew to understand the nonsense of living between the nostalgia for the time bygone and the utopic craving for the future ${ }^{4}$.

The condition described in the short story was diagnosed as an unambiguously negative phenomenon - melancholia made Edward unhappy and deprived him of a will to live ${ }^{5}$. In this approach it becomes synonymous with a disease of the spirit ${ }^{6}$. This is how Kierkegaard understood melancholia - as a sickness requiring healing. According to the Danish philosopher's views, melancholia is a hysteria of the spirit. This feeling means that it longs for a metamorphosis - a transition to a higher form, greater self-awareness, and ethical life. If this does not happen, one develops a disease of melancholia, which, in essence, is equivalent to $\sin$ (Kierkegaard, 2015, p. 165).

In Asnyk's story, the condition of the protagonist was not determined by an adopted religious perspective. However, the way Edward's melancholia developed shows some similarity with the description of this phenomenon and its conceptualization proposed by Kierkegaard - the figure of Nero. In this interpretation, the Roman emperor was a symbol of existence in the purely aesthetic stage: he strove

4 Bieńczyk defines melancholia as a sadness of unknown origin, a longing for an unidentified desire, and a vain search for a lost meaning (2012).

5 Admittedly, this is not the only way to present melancholia. As researchers indicate, throughout history it has been ascribed both negative and positive characteristics. It was often considered an ambivalent phenomenon: melancholia seemed not only to cause suffering but also to be associated with genius and infinite creative potential (Sontag, 1981; Kuczyńska, 1999; Bieńczyk, 2002).

6 The tradition of understanding melancholia as a disease goes back to antiquity. At that time, it was considered a medical condition that caused both spiritual and physical symptoms. Its reasons were seen in bodily conditions (poor functioning of human body fluids). This way of thinking was taken over by later eras, especially the Middle Ages (Klibansky, Panofsky, \& Saxl, 2009). In the end of $19^{\text {th }}$ century, with an arise of modern psychiatry, melancholia started to be classified as mental illness. Nowadays, in medical terms, it is directly associated with depression (Kępiński, 2001). 
for a surfeit of pleasure. His actions were to hide the shallowness of his own existence (pp. 160-165). Edward was also tormented by opposing states of emptiness and repletion. His search for meaning and higher values ends with the conclusion: "Love, fame and all the pleasures of the Earth - they are only miserable masks, from which the gloomy specter of suffering, disappointments and bitterness looks" (Asnyk, 2004, pp. 13-14). He therefore fails to overcome his situation and becomes even more depressed.

The problematic mental state of the protagonist resembles a condition described many years later by Freud and it even shares its symptoms (cf. Freud, 1950, p. 153). Edward suffered due to an experience of a real loss of friendship and love, with the loss of ideals coming as a consequence. He was never quite able to comprehend his own state of mind, complaining about an unclear lack of meaning in life. As a consequence, he became more and more discouraged, as he ceased to take interest in the outside world, losing the ability to build relationships. His life attitude changed, too, and he could no longer function properly. With his mood drastically lowered, he decided to commit suicide.

The moment just before the suicide, planned by the protagonist in a rather unusual way, is the beginning of the short story. Since Edward does not want to do it himself, he challenges to a duel an adversary known for never sparing his opponents. While waiting for the encounter, he decides to walk through a nearby forest, where, due to new sensory experiences, the character unexpectedly faces deeper questions about the meaning of life and what it really takes to save one from listlessness and despair. Creating this very specific narrative situation, Asnyk asks his readers to reconsider the importance of life values significant to the melancholic subject.

The forest is presented in the story as a particular sphere which enables Edward to rebuild his worldview: "The nature is an enormous book, written for sages and simpletons, [...] and everybody finds there a lesson for himself" (Asnyk, 2004, p. 25). It is worth noting that the exceptionality of this space does not come from the subjective attitude of the protagonist. Edward can learn from the forest's nature, because it represents in an objective way a certain system of values. It is not a case of topos mundus melancholicus, which assumes that the world itself is so melancholic that the meaning is replaced with indeterminacy (Bałus, 1996, p. 149). As Bałus astutely observes, "the melancholia of the world is nothing else but the conviction about ambiguity, illegibility ${ }^{7}$, obscurity or lack of foundation on which our reality rises" (p. 135). The world in Asnyk's story has a meaning which can be read from the nature.

While analyzing the poetry of Asnyk, Mocarska-Tycowa (2005) remarks that the way of describing nature, and thus the related discourse, reflect the philosophical

7 All the emphasis in the quotation texts are mine. 
aspect of the writer's understanding of nature and the relationship between the humans and their environs (p. 103). I believe that in the discussed short story, the basic philosophical problem is the search for a way in which to reach the sense of the world inscribed in nature. This question is reduced to the issue of one's contact with nature and other people. Dąbrowska (2013) concludes that in Asnyk's poems nature is accessible to the human aesthetic experience thanks to impressions mediated by the senses. Among them, sight and hearing are particularly privileged (pp. 236-237). In the case of the discussed short story, sight and hearing are also of major significance; however, the conclusion proposed by the researcher is insufficient. It mainly concerns the aesthetic experience of nature. As I will show, experiencing sensory stimuli - visual but above all auditory - is also crucial in the story for a deepened ethical and existential reflection.

Since contact with nature is made possible by the senses, the problem of decoding the life meaning and values, is, in my opinion, contingent on the issue of the perceptive abilities of the melancholic. In the story, this capability is influenced by the external space and, as Asnyk shows, changes once the protagonist enters the forest:

At first mister Edward walked automatically, without paying attention to objects around him. However, slowly, this fresh forest atmosphere, [...] this gentle light, [...] this blissful silence $[\ldots]$ started to exert a beneficial influence on him. [...] His face softened and both the expression of pretended indifference and hidden bitterness disappeared from it [...]. He started looking around (Asnyk, 2004, pp. 6-7).

The stimuli received from the surroundings cause the protagonist to change his attitude through the rejection of melancholic features: indifference and bitterness. His attitude toward the outside world changes from alienation to a positive commitment: "Today, everything interested and attracted Edward" (p. 8). The different, new way of existing in the surrounding reality is closely linked to the change in the protagonist's sensual perception. He is influenced by the play of light and colors as well as the silence and sounds of the forest.

In his definition of the melancholic gaze, Śniedziewski (2018) writes:

the melancholic looks at the world [...] passionlessly. He does not do so in order to see the true nature of reality, its deep implications or hidden meaning [...]. [His gaze] is unable to catch hold of anything (T. D. Williams, Trans., p. 14).

Edward's melancholic gaze that reveals his indifference - aimless and empty, piercing objects and people alike - changes into aesthetic admiration and curiosity. The protagonist begins to appreciate the harmony and the beauty of the landscape. Edward begins to look and listen differently.

I believe that the change in his perception also lies in his sensitivity to auditory stimuli. The protagonist is reached by the sounds. During his walk he listens to: 
"all the fleeting noises that occasionally interrupted the solemn silence of the forest" (Asnyk, 2004, p. 8). Interestingly enough, one of Edward's first auditory experiences was the experience of silence. Although, in this case, not understood as a complete lack of sound. According to Gołaszewska (1997), the forestry audiosphere, despite being full of noises and rustling, may be perceived by people as a sphere of silence, above all because of its otherness and separateness from the city buzz (p. 79). Additionally, Losiak (2011) points out that although silence is often defined as a lack of stimuli, the attainment of such a state is almost impossible in our surroundings. The experience of silence is in fact not an experience of a lack but an experience of a certain presence, most usually related to the space determining its limits. If the said limits are not clearly demarcated, for example as in an open field, the perception of silence can be defined in relation to the listener, whose perception becomes a point of reference for the existence of silence. The experiencing subject is in the center, surrounded by silence; the silence reigns all around (pp. 58-61).

This exact situation is presented in Asnyk's short story: the protagonist ambles through the forest and experiences the silence around him: devoid of the city noise and filled only with the faintest hum of nature. This experience of silence sharpened his perception. That is why receiving the sounds and images around him could become the first step to reading the meaning of life from the book of nature, and, as a consequence, to changing his attitude toward the world.

I think, the process of passing from the melancholic indifference to the contemplation of the world is, then, a way in which one may seek meaning. The contemplation is related, as Bieńczyk (2012) observes, to getting to the essence of things (pp. 80-81) ${ }^{8}$. It is therefore a cognitive activity, which in the case of the short story is equivalent to an attempt at reading the language of nature. It is no coincidence that Asnyk's protagonist makes an effort to contemplate the world in the space of the forest. It is a result of the particularity of this space where the senses are sharpened, and the contact with nature - which favors contemplation - is intensified. This is also confirmed by the statements of other characters. For instance by Cecilia, who understood the sense of the world thanks to being in the bosom of nature. In the conversation with Edward, she refers to the forest as her "temple of meditation" (Asnyk, 2004, p. 25). Arboreal space is created in Asnyk's story as a sacralized place for reflection and a search for meaning.

8 In her interpretation of the Walter Benjamin's views Susan Sontag (1981) proposes a different approach to the relationship between melancholia and contemplation: "Precisely because the melancholy character is haunted by death, it is melancholies who best know how read the world. Or, rather, it is the world which yields itself to the melancholic's scrutiny, as it does to no one else's. The more lifeless things are, the more potent and ingenious can be the mind which contemplates them" (pp. 119-120).

9 Mocarska-Tycowa (2005) concludes that nature for the poet has no sacred features; it only reveals the order present in and of itself. This way of thinking is characteristic of scientific and 
Because of the particularity of the forest, and because of the approaching death, the protagonist gets the strength to sum up his life with honesty, having accidentally encountered a friend from childhood - John who is presently a forester. That is the next step in his search for values: not only does Edward try to understand himself, but he also makes an attempt to openly express his convictions. The protagonist decides to tell his story and confesses what burdens him. This scene, I believe, is crucial for overcoming melancholia by the protagonist. As Kristeva (1989) points out, the problem of melancholy is closely linked with the very nature of language and the loss of capability of speech: "Depressed people know that their moods determine them thoroughly but do not allow such moods to pass into their speech" (p. 46). By defining the discourse as a dialogue, Kristeva indicates that the repetitive speech of a melancholic is not capable of getting into interaction with any other utterance, because once a person utters their loss, the loss is no longer theirs (pp. 31-68). In the conversation with John, Edward not only confesses his misery to a friend, but above all he turns his utterance into a discourse, at the same time opening himself to further dialogue. This is the last, and, as I claim, the most essential step on his way to overcoming melancholia - listening closely to another person.

John's responses convey the meaning of the story. According to him, the right way for living consists of working and caring for the loved ones, awareness of one's place in the world and readiness to take on the one's duties. The forester's advice concerns the way of existing around people and the appropriate attitude toward them, which should be altruistic and responsible. To prove the efficacy of such a solution, John invites Edward to his house, which stands in the middle of the forest, inconspicuously blending in with its surroundings, as if it had grown into the landscape. This is where the other members of John's family belong, above all his sister-in-law, Cecilia who is described by protagonist as a dryad or a forest spirit. She and the forester - sensitive to the teachings of the woods know how to read the book of nature.

Cecilia claims that her thoughts, "pass, almost unconsciously, through her mind, tuned to the note of the rustling forest" (Asnyk, 2004, p. 25). Listening to this particular forest silence leads to a reflection about the meaning of life: "When I'm alone in the forest, I can easily think and wander, and it seems to me then, that I understand a lot and I can tell what I comprehend" (p. 26). That is how the girl becomes the representative of the truths of the forest, truths which concern

secular views dominating in the second half of the $19^{\text {th }}$ century (p. 117). My interpretation does not in the least suggest that nature in Asnyk's short story leads to transcendence or enables an experience of God, but it does however draw attention to the specific way of creating the space of the forest (here identified as a sacralized place), considering not only its aesthetic dimension but also its ethical and existential underpinning. As I will show later in the article, the meaning revealed by this space is not religious. 
the structure of the reality itself as well as the justification for the way of life advocated by John.

Ruminating upon the woods, Cecilia notices:

an arrangement so harmonious, so appropriately applied [...]. I was immediately struck by a very visible thought that everything that [...] exists, struggles to realize within the limits of its type the highest degree of beauty, desiring to achieve greater and greater perfection, and at the same time to achieve harmony with all of its surroundings. [...] Because of this idea [of harmony] everything what is miserable and stunted is lost (pp. 26-27).

The girl is able to reach the essence of the world: its harmonious structure. It is revealed to her through visual and sound stimuli. This objective truth (at least according to the story) can be juxtaposed with the melancholic attitude toward reality, where, as Bieńczyk (2012) points out, the world is an unharmonious being, overfilled with beings not fitting into any hierarchy, not narrowing the sense to a specific meaning (pp. 42-43). Understanding this truth about the order of reality brings consolation and, at the same time, a hint about "existing in the world," and the possibility of finding happiness. According to Cecilia, the harmony and the beauty of nature should be reflected in the human soul. She claims it is human destiny to improve oneself and this is the necessary condition of life and of development. The aim of this process is also to pursue beauty, which in this case is synonymous with happiness. Cecilia asks: "Can anyone be unhappy while feeling a part of general thought, general harmony, a sound in the melodious choir of existence, a color essential for the whole painting?" (Asnyk, 2004, p. 28).

The life stance represented by John and Cecilia partially coincides with the Polish Positivist school of thinking, especially where it regards collectivity as superior to individuality, emphasizing the hierarchy of social structures and calling for work for the benefit of the community (also undertaken by outstanding individuals) (cf. Borkowska, 1996, pp. 31-48). In the descriptions of the world's structure presented by Cecilia, one can see references to determinism and the theory of evolution (Baczewski, 1984, p. 291). According to Darwin (1861), "natural selection works solely by and for the good of each being, all corporeal and mental endowments will tend to progress towards perfection" (p. 425). The interpretation of reality presented in Asnyk's story is therefore a secular reflection intrinsically grounded in the social and scientific approach to reality.

Thus, the proper existence of a person demands harmony, understood as the ability to place oneself within the order or the structure of the world (Dąbrowska, 2013, p. 290). This is the purpose and meaning of life presented in the story. The forester's family adapted to this model and consequently found happiness. One of the first impressions that Edward experiences when entering their house is the pervading sense of harmony. 
As an immediate result of the conversation, the protagonist finally fathoms how he should behave to mitigate his sadness. Understanding this truth was possible on account of the affirmation of another person's life view. Edward pays attention both to what Cecilia says and how she sounds: "The silver, melodic sound of her voice was a completion of what was, until now, a miraculous vision for Edward" (Asnyk, 2004, p. 24). He reacts in a similar way to John's words: "He seemed to recognize the sincere, noble sound of his speech, and it moved in the strings of his soul, silenced a long time ago" (p. 12). In this sense, the experiences of the protagonist are also shaped by the sound of human voice.

The beautiful melody of the forester's and his sister-in-law's voices as if confirms the truth of their words. By means of simple conversation, Edward gets to know and understand their beliefs, and their presence in his life disabused him of his exalted notion of suffering, thereby alleviating his lingering melancholia. In my opinion, all of these changes were possible thanks to the attitude of the listener: "He felt perfectly that during the last hour he was just a listening student" (p. 30). Asnyk shows that opening to auditory experiences toward the sounds of space and the words of another person may allow one to find a cure for melancholia symptoms, nullifying indifference toward people and things as well as encouraging social interaction.

I have shown earlier that the starting point in Asnyk's work is looking at beauty of the world and listening to it. This can be the first step on the road to regaining one's equilibrium, a sense of self, and even a validation of one's life values. In last scenes of the story, this issue returns, as the protagonist again pays attention to his immediate environs. The reader is presented with an extensive description of the arboreal space as well as Edward's reaction to it:

[He] looked into the world through his eyes. The sun was just going down [...]. Streaks of light broke through the branches brightly [...]. Forest birds screaming and twittering circled busy above the trees [...]. Above their heads - pure blue became deeper and deeper in color, although still permeated with brightness. Around them, the trees rustled in a soft, barely audible murmur, as if they were just saying a quiet evening prayer. It all pervaded the viewer with $a$ strangely soft and powerful feeling (pp. 34-35).

The abovementioned quotation is a description of a soundscape. The concept of a soundscape, constructed in response to and on the basis of the visual category of a landscape, encourages to pay special attention to the sphere of sounds, whose conceptualization allows one to examine information about both the aesthetic and ethical values of a space. As Losiak (2015) argues, a soundscape (likewise a landscape) is perceived individually, however, this reception is culturally conditioned (pp. 46-52). This situation is presented in Asnyk's story, where the iconosphere and the audiosphere are presented from the protagonist's perspective and interpreted by him as a system of signs communicating certain 
values. Finding oneself in such a perceived reality requires adopting the listener's attitude, an active stance completely incompatible with melancholic indifference. It encourages listening-in-readiness. Thanks to it, it is possible to establish the relationship with others and with the reality itself.

At the end of the story the protagonist sums up his experiences, all prior to his confessor, John. Edward directly agrees with the beliefs of the forester and his family, and he asks to be buried "among the forest" (Asnyk, 2004, p. 37). This gesture is a confirmation of his identification with the values represented by this space. It seems that Asnyk created a didactic story in which he expressed his views on the right way of life and the possibility of overcoming melancholia.

\section{Conclusion}

In the conclusion, I would like to bring into focus one more issue, which - though seemingly emphasizing the meaning of the story - greatly complicates its content. It is the use of irony in the narrative. Cecilia and John's Positivist views are juxtaposed with Edward's individualistic, passive, and de facto, egoistic stance. His character and attitude to the world are devalued from the narrative perspective through the use of irony, as patently visible in the following example: "Edward didn't spare his words to convince his friend about the enormity of misfortunes which he - much like a modern Atlas - had to carry on his shoulders" (p. 13). The hyperbolized simile, grounded deeply in an irony, brings attention to a clearly discernible contrast of characterial attitudes to life as much as it seems to reveal which views Asnyk himself sympathized with.

The issue gets more complex, however, when one takes into account the title under which the short story was initially published, that is Powiastki dla dorostych dzieci: Wśród lasu [Small Tales for the Grown-up Children: Among the Forest]. Both the diminutive applied at the beginning and the directing of the short story to "adult children" makes one think about a fairy tale convention. At the same time it indicates distance as a superior category in the story, clearly suggesting it might just as well be read ironically.

I believe that in order to decipher the possible reasons for the use of such a solution by Asnyk, it is worth returning once again to the views of Kierkegaard. In his reflections on melancholia, he also addressed the issue of irony. According to Starobinski (2017), the Danish philosopher believes that irony is not a force that defeats melancholia, it is rather the other side of it (p. 281). Herer (1998) described it as a "mask of melancholia," indicating that, according to Kierkegaard, irony only seemingly contradicts the melancholic's passivity. In its essence, it is a negating attitude. Therefore, it leads at most to the void confirming the original state of sadness (p. 83).

I suggest looking at the use of irony by Asnyk in a similar way. Its use appears to be an indication that the effectiveness of the cure for melancholia presented in the short story is lined with doubt and distance - both deeply melancholic in their 
nature. Asnyk, about whom Borkowska (1996) writes "in Polish literature, [he] is par excellence an embodiment of a melancholic poet" (p. 163), chooses an interesting way to reveal himself ${ }^{10}$. Positivistic worldview loses the status of an answer to the question about the meaning of life and the possibility of achieving happiness. So how can one address the search of a cure for melancholia described in the story?

\section{Acknowledgements}

This work was created with the financial support obtained from the Integrated Development Programme of the University of Warsaw (ZIP), co-financed by the European Social Fund, under the Operational Program Knowledge Education Development for 2014-2020, path 3.5.

\section{References}

Asnyk, A. (2004). Wśród lasu. Opowiadania. Kraków: Universitas.

Baczewski, A. (1984). Twórczość Adama Asnyka. Rzeszów: Wydawnictwo Wyższej Szkoły Pedagogicznej.

Bałus, W. (1996). Mundus melancholicus. Melancholiczny świat w zwierciadle sztuki. Kraków: Universitas.

Bieńczyk, M. (2002). Oczy Dürera. O melancholii romantycznej. Warszawa: Sic!.

Bieńczyk, M. (2012). Melancholia. O tych, co nigdy nie odnajda straty. Warszawa: Sic!.

Borkowska, G. (1996). Pozytywiści i inni. Warszawa: Państwowe Wydawnictwo Naukowe.

Budrewicz, T. (2015). Rymowane spory. Asnyk. Kraków: Wydawnictwo Naukowe Uniwersutetu Pedagogicznego.

Darwin, Ch. (1861). On the Origin of Species or the Preservation of Favoured Races in the Struggle for Life. Ney York: D. Appleton and Company. Retrieved September 15, 2019, from http:// darwin-online.org.uk/converted/pdf/1861_OriginNY_F382.pdf.

Dąbrowska, A. (2013). Literackie obrazy natury w twórczości poetyckiej Adama Asnyka. Bydgoszcz: Wydawnictwo Uniwersytetu Kazimierza Wielkiego.

Freud, S. (1950). Mourning and Melancholia. Collected Papers, 152-170. London: Hogarth Press. Gołaszewska, M. (1997). Estetyka pięciu zmystów. Warszawa: Państwowe Wydawnictwo Naukowe. Herer, M. (1998). Od melancholii do wiary. Sztuka i filozofia, 15, 76-87.

Kępiński, A. (2001). Melancholia. Kraków: Wydawnictwo Literackie.

Kierkegaard, S. (2015). Albo - albo, Vol. 2 (M. Hammermeister, Trans.). Gdańsk: słowo/obraz terytoria.

Klibansky, R., Panofsky, E., \& Saxl, F. (2009). Saturn i melancholia. Studia z historii, filozofii, przyrody, medycyny, religii oraz sztuki (A. Kryczyńska, Trans.). Kraków: Universitas.

Kristeva, J. (1989). Black Sun. Depression and Melancholia (L. S. Roudiez, Trans.). New York: Columbia.

Kuczyńska, A. (1999). Piękny stan melancholii. Filozofia niedosytu i sztuka. Warszawa: Wydział Filozofii i Socjologii Uniwersytetu Warszawskiego.

${ }^{10}$ In his generation, not only Asnyk experienced melancholia. In the late $19^{\text {th }}$ century, this kind of feeling was common among creators of the Polish Positivist school of thinking such as Aleksander Świętochowski (Paczoska, 2002), Bolesław Prus (Mazur, 2001) and Eliza Orzeszkowa (Mazur, 2010). The crisis of their worldview was rooted in a very specific political and social conditions (above all in the occupation of Poland). Płachecki (2009) observes a similar phenomenon (which he identifies as a specific kind of decadent attitude), analyzing the poetry of the 1860s and 1870s (pp. 287-309). 
Losiak, R. (2011). Cisza w doświadczeniu audiosfery współczesnej. In J. Harbanowicz, \& A. Janiak (Eds.), Przestrzeń ciszy. Przestrzenie wizualne i akustyczne człowieka. Antropologia wizualna jako przedmiot i metoda badań 2 (pp. 57-64). Wrocław: Wydawnictwo Naukowe Dolnośląskiej Szkoły Wyższej.

Losiak, R. (2015). Malowniczość pejzażu dźwiękowego. O pewnym aspekcie estetycznego doświadczania audiosfery. Teksty Drugie, 5, 45-57.

Mazur, A. (2001). Kosmiczna melancholia Prusa. In G. Borkowska, \& J. Wójcicki (Eds.). Pogranicza literatury. Księga ofiarowana Profesorowi Januszowi Maciejewskiemu na Jego siedemdziesięciolecie (pp. 156-161). Warszawa: Instytut Badań Literackich PAN.

Mazur, A. (2010). Pod znakiem Saturna. Topika melancholii w późnej twórczości Elizy Orzeszkowej. Opole: Wydawnictwo Uniwersytetu Opolskiego.

Misiak, T. (2009). Estetyczne konteksty audiosfery. Poznań: Wydawnictwo Wyższej Szkoły Nauk Humanistycznych i Dziennikarstwa.

Mocarska-Tycowa, Z. (2005). Wybory i konieczności. Poezja Adama Asnyk wobec gustów estetycznych $i$ najważniejszych pytań swoich czasów. Toruń: Wydawnictwo Uniwersytetu Mikołaja Kopernika.

Nacher, A. (2010). Komponować świat, słuchając - dźwięk jako komunikacja. Przegląd Kulturoznawczy, 1, 75-86.

Nofer, A. (1965). Adam Asnyk. 1838-1897. Obraz literatury polskiej XIX i XX Wieku. Literatura polska w okresie realizmu i naturalizmu, Vol. 1. (pp. 165-209). Warszawa: Państwowe Wydawnictwo Naukowe.

Paczoska, E. (2002). Wstęp. In A. Świętochowski. Dumania pesymisty (pp. 5-32). Warszawa: Sic!.

Płachecki, M. (2009). Wojny domowe. Szkice z antropologii słowa publicznego $w$ dobie zaborów (1800-1880). Warszawa: Wydawnictwo Instytutu Filozofii i Socjologii PAN.

Schafer R. M. (1977). The Tuning of the World, New York: Knopf.

Sontag, S. (1981). Under the Sign of Saturn. New York: Farrar, Straus, \& Giroux.

Starobinski, J. (2017). Atrament melancholii (K. Belaid, Trans.). Gdańsk: słowo/obraz terytoria.

Śniedziewski, P. (2018). The Melancholic Gaze (T. D. Williams, Trans.). Frankfurt am Main: Peter Lang Verlag.

Truax, B. (1984). Acoustic Communication. New Jersey: Ablex Publishing. 